\title{
The value of political connections and Sharia compliance during the COVID-19 pandemic
}

\section{Budi Wahyono ${ }^{1,2}$ (D)}

Received: 12 February 2021 / Revised: 16 September 2021 / Accepted: 17 December 2021 /

Published online: 18 January 2022

(c) The Author(s) under exclusive licence to Eurasia Business and Economics Society 2022

\begin{abstract}
The relationship between the COVID-19 pandemic and the stock market has been well documented in other studies. However, thus far, researchers have shown little interest in the role of political connections and Sharia compliance during the pandemic. This study offers novel evidence by investigating the value of both political connections and Sharia compliance during the present pandemic. We use two kinds of analysis. First, using the event-study methodology, we measure the stock market reaction to the COVID-19 pandemic. Second, to further sharpen our identification of the value of political connections and Sharia compliance during the current pandemic, we use a pooled regression analysis. We find that there was a stock market anomaly during the COVID-19 pandemic in Indonesia in that the pandemic had a positive impact on the stock market. We also find that there was value for firms in being Sharia-compliant during the pandemic when the government announced tax incentives for firms. Based on these results, we offer insights relevant to policymakers and financial market authorities seeking to enhance the effectiveness of policy measures during the COVID-19 pandemic. In addition, our study also has important implications for individual investors.
\end{abstract}

Keywords COVID-19 $\cdot$ Political connections $\cdot$ Sharia $\cdot$ Stock market $\cdot$ Indonesia

JEL Classification G14 · G17 · G32 · D72 · Z12

Budi Wahyono

budiwahyono@staff.uns.ac.id

1 The Graduate School of East Asian Studies, Yamaguchi University, 1677-1, Yoshida, Yamaguchi-shi 753-8514, Japan

2 Department of Economics Education, Universitas Sebelas Maret, J1. Ir. Sutami 36A, Surakarta 57126, Indonesia 


\section{Introduction}

The first case of COVID-19 was confirmed in Wuhan city, China, on December 31, 2019 (WHO, 2020b). The global spread of the disease was confirmed and it was declared a pandemic on March 11, 2020 (WHO, 2020a). In Indonesia, the first case was confirmed on March 2, 2020, and the first case of death was confirmed on March 11, 2020. Figure 1 shows the daily total active cases and daily total deaths caused by COVID-19 in Indonesia.

The spread of COVID-19 is having a major impact on economic activity in Indonesia, as can be seen, for example, from the movement of stock market returns. The stock market responds to major events, and data reflecting investors' reactions are updated and made available rapidly (Al-Awadhi et al., 2020; Griffith et al., 2020). Moreover, the stock market reactions to COVID-19 have useful and timely implications for policymaking (Griffith et al., 2020; Wagner, 2020). Figure 2 summarizes the cumulative average daily stock market returns, showing that the stock market reacted to the COVID-19 outbreak and that stock market returns were somewhat volatile when the first case of COVID-19 was confirmed in Indonesia.

The literature on the relationship between the COVID-19 pandemic and the stock market is expanding rapidly. Some previous studies have examined the impact of the COVID-19 pandemic on stock market performance. One of the main conclusions is that stock markets reacted negatively to the growth of COVID-19 cases (Al-Awadhi et al., 2020; Ashraf, 2020; Liu et al., 2020; Topcu \& Gulal, 2020). Other studies have examined the relationship between the COVID-19 pandemic and stock market volatility (Baek et al., 2020; Fakhfekh et al., 2021; Hong et al., 2021) and economic policy uncertainty (Sharif et al., 2020; Youssef et al., 2021). Some prior research has also investigated the effect of COVID-19 on socially responsible investing (Omura et al., 2021) and faith-based (Sharia) investment (Sherif, 2020). Although the relationship between the COVID-19 pandemic and the stock market is well documented in the literature, thus far, no study has explored the role of political connections and Sharia compliance during the pandemic. We fill this gap by estimating the value of political connections and of Sharia compliance in certain episodes during the pandemic, i.e., when the first case of COVID-19 was confirmed, when the first death
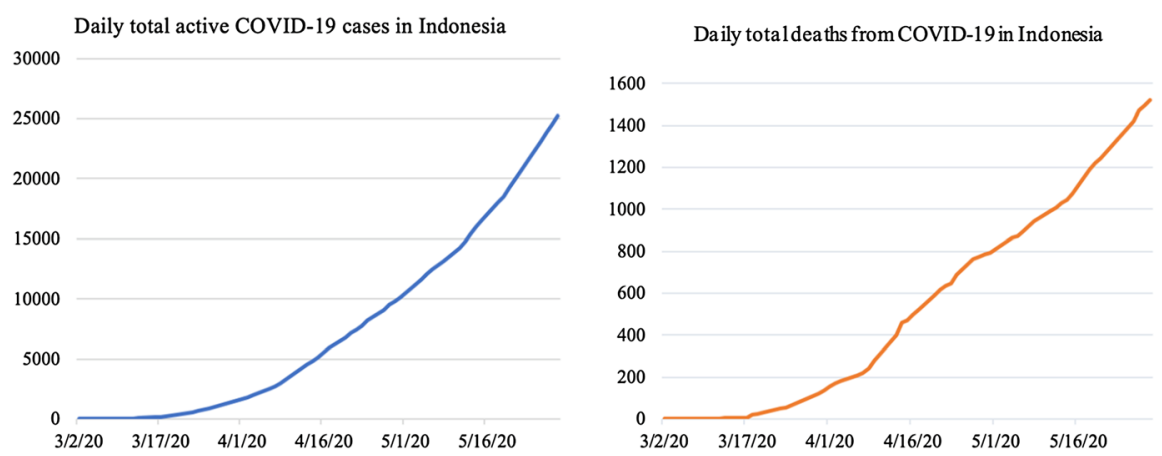

Fig. 1 Total daily cases and deaths caused by COVID-19. Source: Worldometer 


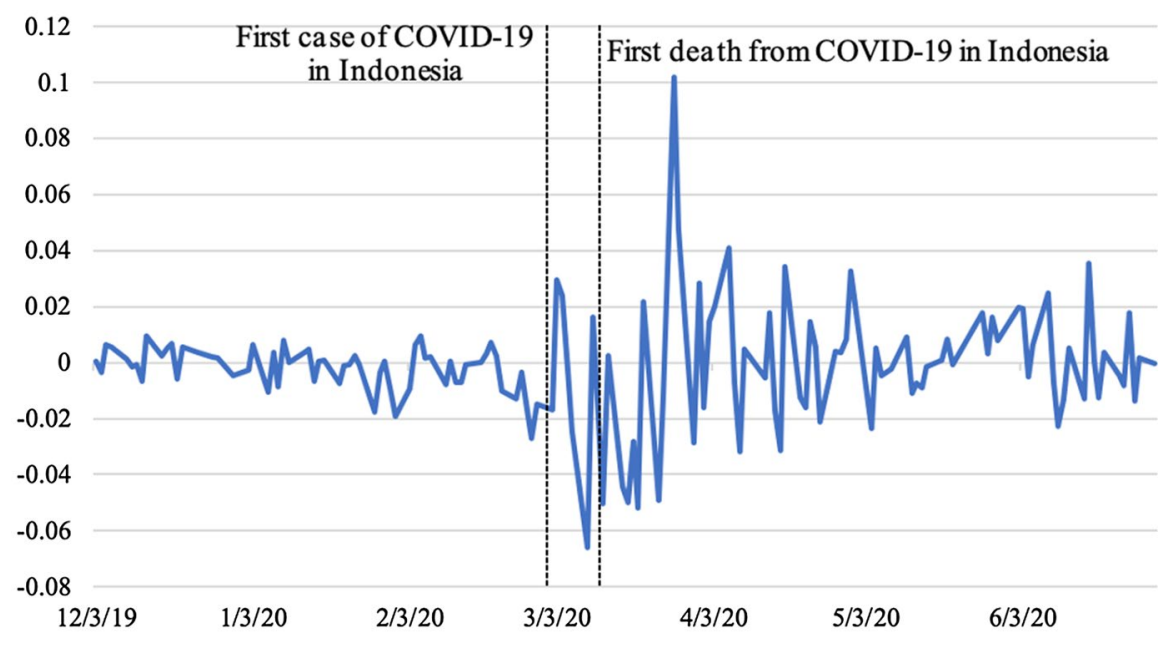

Fig. 2 Cumulative average daily stock market returns. Source: Yahoo Finance

caused by COVID-19 was confirmed, and when the government announced the stimulus package in the form of tax incentives for firms.

Investigating the value of political connections and Sharia compliance during the COVID-19 pandemic is interesting for several reasons. First, many firms needed funds to continue to operate during the pandemic, which they were able to raise by issuing bonds or securing loans from banks. Politically connected firms may have wider access to funding - they are more likely to be funded, bailed out by the government, or to be able to borrow from state-owned banks (Duchin \& Sosyura, 2012; Faccio et al., 2006; Fu et al., 2017). A study by Wang and Lin (2017) found that politically connected firms receive higher subsidies from the government. In the context of economic distress, Vukovic (2021) found that political connections tended to increase bailout packages in relative terms for connected firms during the 2008/2009 global financial crisis. However, the COVID-19 pandemic is unprecedented-it is unlike the global financial crisis of 2008/2009 or any other previous infectious disease outbreak (Baker et al., 2020). The question is, then, has being politically connected also been valuable during the COVID-19 pandemic? To the best of our knowledge, no empirical evidence regarding this matter has yet been presented.

Second, several previous studies have shown that being Sharia-compliant can be beneficial to firms, especially during major events such as the global financial crisis and the COVID-19 pandemic. For example, Al-Khazali et al. (2014) and Al-Suhaibani and Naifar (2014) found that Sharia-compliant firms outperformed non-Shariacompliant firms during the global financial crisis of 2008/2009. Another study by Abduh (2020) found that Sharia-compliant firms were less volatile than non-Sharia-compliant firms during the financial crisis. Furthermore, in the context of the COVID-19 pandemic, Sherif (2020) found that the pandemic has had an insignificant impact on the stock returns of Sharia-compliant firms. Similarly, Ryandono 
et al. (2021) suggested that Sharia-compliant firms have responded more quickly to COVID-19. However, few studies have attempted to address the role of Sharia compliance during the current pandemic.

Third, although both political connections and Sharia compliance may have been beneficial during the COVID-19 pandemic, there are several contradictions between them. Political connections motivate tunneling and facilitate opportunistic behavior by insiders (Hu et al., 2020; Jagolinzer et al., 2020). Politically connected firms have the potential to expropriate minority shareholders through tunneling (Qian et al., 2012). Conversely, Sharia-compliant firms are required to follow Islamic principles and maximize shareholders' wealth (Safieddine, 2009). In addition, Sharia compliance constraints opportunistic behavior by firms' boards (Farooq \& AbdelBari, 2015). These concerns motivate our study.

The contribution of this study is twofold. First, this study fills the research gap regarding the relationship between political connections and the COVID-19 pandemic. As mentioned before, thus far, no study has investigated the role of political connections during the current pandemic. Second, this study contributes to the literature on the COVID-19 pandemic and the Islamic stock market, following explorations by Sherif (2020) and Ryandono et al. (2021). Specifically, this study provides insight into the valuation of Sharia compliance during some episodes of the COVID-19 pandemic. Apart from its theoretical contributions, this paper will also be of interest to policymakers, market authorities, and individual investors who wish to know whether or not political connections and Sharia compliance have been valuable during the current pandemic.

The remainder of this paper proceeds as follows. Section 2 describes the research data and methodology. Section 3 presents the results of an event-study analysis, pooled regression analysis, and robustness checks and discusses them. Finally, Sect. 4 presents the concluding remarks and discusses the implications and some limitations of this study.

\section{Data and methodology}

\subsection{Sample screening}

We use data for companies listed on the Indonesia Stock Exchange (IDX). Our sample consists of 592 listed firms. We categorized our sample into politically connected firms and Sharia-compliant firms. We follow Faccio (2006) and Habib et al. (2017) in considering a firm to be politically connected if it is state-owned or if any of the larger shareholders (with ownership of more than 10\%) or top management are current or former (a) members of parliament, (b) ministers or heads of state, (c) or people who have a close relationship ${ }^{1}$ with top officials. We took the names of the board commissioners and directors from the IDX and then traced the board

\footnotetext{
1 A relationship is defined here as being a friend or well-known associate of a political party (Faccio 2006).
} 
Table 1 Variable definitions

\begin{tabular}{|c|c|}
\hline Variable & Definition \\
\hline \multicolumn{2}{|l|}{ Panel A: Event-study analysis } \\
\hline Cumulative abnormal returns & $\begin{array}{l}\text { The abnormal return is the difference between the actual return } \\
\text { and the expected return, calculated by the basic market model } \\
\text { (detailed calculation of CAR is presented in Sect. } 2.3 \text { ) }\end{array}$ \\
\hline \multicolumn{2}{|l|}{ Panel B: Pooled regression analysis } \\
\hline Stock return & $\begin{array}{l}\text { Daily stock return calculated by the difference between the closing } \\
\text { price on one day and the previous day }\end{array}$ \\
\hline Political connections & $\begin{array}{l}\text { We define political connections using a dummy variable to repre- } \\
\text { sent a politically connected firm, which is equal to } 1 \text { if the firm } \\
\text { is politically connected and } 0 \text { otherwise (the criteria for political } \\
\text { connections are presented in Sect. } 2.1 \text { ) }\end{array}$ \\
\hline Sharia compliance & $\begin{array}{l}\text { We define Sharia compliance as a firm with Sharia stocks (listed in } \\
\text { the ISSI), using a dummy variable that is equal to } 1 \text { if listed in the } \\
\text { ISSI and } 0 \text { otherwise }\end{array}$ \\
\hline Market return & $\begin{array}{l}\text { Daily market return, i.e., the daily return on the Composite Stock } \\
\text { Price Index (IHSG) }\end{array}$ \\
\hline Market capitalization & Natural logarithm of daily market capitalization \\
\hline
\end{tabular}

members' profiles manually from the firms' annual reports and official websites. In addition, we obtained data on shareholders from the IDX. Furthermore, we categorized a firm as being Sharia-compliant if it was listed on the Indonesia Sharia Index (ISSI). Data on the ISSI-listed firms were obtained from the IDX.

\subsection{Variable measurement}

This study uses two kinds of analysis, i.e., event-study and panel regression analysis (using the pooled method). We use several variables in our analysis. First, for the event-study analysis, we use cumulative abnormal returns (CAR) as the variable (i.e., we determine the significance of CAR). Second, for panel regression analysis, we use daily stock return as the dependent variable and political connections and Sharia compliance as independent variables, with daily market return and daily market capitalization as control variables. Table 1 summarizes the variable definitions for our analysis.

\subsection{Event-study methodology}

We rely on a basic event-study methodology to examine the impact of the COVID19 pandemic on the stock performance of politically connected firms and of Shariacompliant firms. To calculate abnormal returns, we employ the basic market model described by Brown and Warner (1985) as follows:

$$
\mathrm{A}_{i, t}=\mathrm{R}_{i, t}-\alpha_{i}-\beta_{i} \mathrm{R}_{m, t}
$$


where $\mathrm{A}_{i, t}$ is the abnormal return for security $i$ at day $t, \mathrm{R}_{i, t}$ is the observed arithmetic return for security $i$ at day $t, \alpha_{i}$ is the intercept, $\beta_{i}$ is the slope, and $\mathrm{R}_{m, t}$ is the return on the IHSG for day $t$. We obtained daily stock prices from the IDX and Yahoo Finance and then documented daily returns based on the closing stock prices. The event date is March 2, 2020, that is, the date when the first case of COVID-19 was announced. Following MacKinlay (1997), this study uses 120 trading days as an estimation window, i.e., from - 140 to -20 days prior to the event date. We calculate CAR by cumulating $\mathrm{A}_{i, t}$ over the announcement period.

$$
\operatorname{CAR}\left[t_{1}, t_{2}\right]=\sum_{t=t_{1}}^{t_{2}} \mathrm{~A}_{i, t} .
$$

Finally, we test the significance of the CAR using a $t$-test. Following Chen et al. (2007), if the CAR is significantly different from zero, the event is considered to have significantly impacted stock prices. We divide the sample into four sub-samples, namely politically connected non-Sharia-compliant firms, non-politically connected Sharia-compliant firms, politically connected Sharia-compliant firms, and non-politically connected non-Sharia-compliant firms. Then, we investigate the impact of the COVID-19 pandemic on each sub-sample.

\subsection{Regression model}

We employ a panel regression analysis to sharpen our further identification of the role of political connections and Sharia compliance during the COVID-19 pandemic. Inspired by Fisman (2001), we divide our analysis into several episodes. We use three episodes in our regression analysis, i.e., the date the first case of COVID19 was confirmed, the date the first case of a death caused by COVID-19 was confirmed, and the date of the government announcement of tax incentives for firms. The first case of COVID-19 in Indonesia was confirmed on March 2, 2020 (our episode is from March 2 to March 4, 2020), and the first death caused by COVID-19 in Indonesia was confirmed on March 11, 2020 (our episode is from March 11 to March 13, 2020). Then, on March 26, 2020 (our episode is from March 26 to March 30, 2020), the Indonesian government announced through the Ministry of Finance that companies would receive tax incentives on account of the COVID-19 pandemic. Each episode consists of three trading days. Thus, our sample in this regression analysis is 1,776 observations from 592 firms for each episode.

To investigate whether it was worth it for firms to be politically connected or Sharia-compliant during each episode, we run a set of panel data regression using the following model:

$$
\mathrm{R}_{i, t}=\alpha+\beta_{1} \mathrm{PC}_{i}+\beta_{2} \mathrm{SH}_{i}+\beta_{3} \mathrm{PC}_{i} * \mathrm{SH}_{i}+\beta_{4} \mathrm{MR}_{t}+\beta_{5} \mathrm{LNMC}_{i, t}+\varepsilon_{i, t}
$$

where $\mathrm{R}_{i, t}$ is stock return $i$ during episode $t, \mathrm{PC}_{i}$ is political connections, $\mathrm{SH}_{i}$ is Sharia, $\mathrm{MR}_{t}$ is the market return during episode $t, \mathrm{LNMC}_{i, t}$ is the natural logarithm of daily market capitalization, and $\varepsilon_{i, t}$ is the error term. The data for daily stock prices and daily market prices (IHSG) were taken from the IDX and Yahoo Finance. 
Additionally, we obtained data on daily market capitalization from The Indonesia Capital Market Institute (TICMI). Following Jagolinzer et al. (2020)—who employ single country regressions in their study-we estimate our model using a pooled regression analysis. In addition, we also conduct a Breusch-Pagan Lagrange Multiplier test to confirm the model selection (see Appendix 1). The results of the Breusch-Pagan Lagrange Multiplier test show that the null hypotheses are accepted and confirm that the pooled regression is appropriate for our analysis.

\section{Results and discussions}

\subsection{Descriptive statistics and correlation matrix}

We first report the descriptive statistics in Table 2. Panel A of Table 2 elucidates the descriptive statistics of CAR that are used in the event-study analysis. Panels B, $\mathrm{C}$, and D of Table 2 show the descriptive statistics of our regression variables. It is apparent from Panel A of Table 2 that the mean of CAR before the event date was negative but positive after the event date, indicating a positive trend in CAR after the first case of COVID-19 was confirmed. Panels B, C, and D of Table 2 show that approximately $42.06 \%$ and $64.70 \%$ of the total sample were politically connected firms and Sharia-compliant firms, respectively. Table 3 shows the correlation matrix between all variables that are used in the regression analysis. In general, the coefficient correlations of all variables are small, indicating that multicollinearity is not an issue in our analysis.

\subsection{Event study}

\subsubsection{Baseline analysis}

Figure 3 presents the CAR for each sub-sample surrounding the event date on March 2, 2020. Table 2 shows the results for the event-study mean using a basic market model.

The results shown in Fig. 3 indicate an inward trend in CAR. Particularly, the inward trend in CAR is more pronounced after the event window [0,20], i.e., around the end of March 2020. At the end of March 2020-more precisely, on March 26, 2020 - the government of Indonesia announced that it would give tax incentives to firms. It is reasonable to suppose that CAR's strength after the event window $[0,20]$ was because the market responded positively to the government announcement of tax incentives for firms.

As reported in Table 4, the estimate of CAR before the event date was statistically negatively significant for politically connected non-Sharia-compliant firms, nonpolitically connected Sharia-compliant firms, and politically connected Sharia-compliant firms. These results indicate that the market reacted negatively before the first case of COVID-19 in Indonesia was confirmed. The market reacted negatively only during the event window $[-30,0]$ for politically connected non-Sharia-compliant 
Table 2 Descriptive statistics

\begin{tabular}{|c|c|c|c|c|c|}
\hline Variable & $\mathrm{N}$ & Mean & S.D & Min & Max \\
\hline \multicolumn{6}{|c|}{ Panel A: Event study } \\
\hline CAR $[-30,0]$ & 592 & -0.0415 & 0.2168 & -1.2067 & 0.9115 \\
\hline CAR $[-20,0]$ & 592 & -0.0216 & 0.1895 & -0.9980 & 0.9499 \\
\hline $\operatorname{CAR}[-10,0]$ & 592 & -0.0112 & 0.1515 & -0.9420 & 1.0571 \\
\hline CAR $[-5$, & 592 & -0.0140 & 0.1225 & -0.6647 & 0.7611 \\
\hline CAR $[-3,0]$ & 592 & -0.0089 & 0.1009 & -0.5292 & 0.5432 \\
\hline CAR $[0,0]$ & 592 & 0.0048 & 0.0576 & -0.2625 & 0.3728 \\
\hline CAR & 5 & 0.0 & & & 0.7402 \\
\hline $\mathrm{CA}$ & 592 & 0.0159 & 0.1212 & -0 . & 0.8343 \\
\hline CAR $[0,10]$ & 592 & 0.0063 & 0.1752 & -0.8805 & 0.9161 \\
\hline CAR $[0,20]$ & 592 & -0.0011 & 0.2701 & -1.5619 & 1.6905 \\
\hline CAR $[0,30]$ & 592 & 0.0400 & 0.2926 & -1.5346 & 1.6940 \\
\hline
\end{tabular}

Panel B: Pooled regression analysis (March 2-4, 2020)

$\begin{array}{llrlll}\text { R } & 1776 & 0.0093 & 0.0557 & -0.3350 & 0.3496 \\ \text { PC } & 1776 & 0.4206 & 0.4938 & 0 & 1 \\ \text { SH } & 1776 & 0.6470 & 0.4780 & 0 & 1 \\ \text { MR } & 1776 & 0.0121 & 0.0206 & -0.0168 & 0.0294 \\ \text { LNMC } & 1776 & 27.8695 & 1.9331 & 22.9205 & 34.2979\end{array}$

Panel C: Pooled regression analysis (March 11-13, 2020)

$\begin{array}{lrrrll}\text { R } & 1776 & -0.0114 & 0.2022 & -0.1821 & 8.2788 \\ \text { PC } & 1776 & 0.4206 & 0.4938 & 0 & 1 \\ \text { SH } & 1776 & 0.6470 & 0.4780 & 0 & 1 \\ \text { MR } & 1776 & -0.0202 & 0.0221 & -0.0501 & 0.0024 \\ \text { LNMC } & 1776 & 27.8031 & 1.9068 & 22.9205 & 34.2018\end{array}$

Panel D: Pooled regression analysis (March 26-30, 2020)

$\begin{array}{lrrrll}\text { R } & 1776 & 0.0140 & 0.0689 & -0.8121 & 0.3478 \\ \text { PC } & 1776 & 0.4206 & 0.4938 & 0 & 1 \\ \text { SH } & 1776 & 0.6470 & 0.4780 & 0 & 1 \\ \text { MR } & 1776 & 0.0402 & 0.0536 & -0.0288 & 0.1019 \\ \text { LNMC } & 1776 & 27.7265 & 1.8744 & 22.9205 & 34.1420\end{array}$

$C A R$ cumulative abnormal return, $R$ daily stock return, $P C$ political connections, $S H$ Sharia compliance, $M R$ daily market return, $L N M C$ natural logarithm of daily market capitalization

firms and $[-20,0]$ for politically connected Sharia-compliant firms. Meanwhile, the market value of non-politically connected Sharia-compliant firms was significantly negatively affected for all event windows prior to the event date. Furthermore, the market value of non-politically connected non-Sharia-compliant firms before the event date was negatively affected but to an insignificant extent.

Interestingly, the estimate of CAR after the event date was statistically positively significant across all sub-samples. These results indicate that there was a stock market anomaly when the first case of COVID-19 in Indonesia was confirmed. That is, although there was volatility in stock returns during the COVID-19 pandemic, 
Table 3 Correlation matrix

\begin{tabular}{|c|c|c|c|c|c|}
\hline & $\mathrm{R}$ & $\mathrm{PC}$ & $\mathrm{SH}$ & MR & LNMC \\
\hline \multicolumn{6}{|c|}{ Panel A: March 2-4, 2020} \\
\hline $\mathrm{R}$ & 1 & & & & \\
\hline $\mathrm{PC}$ & 0.0256 & 1 & & & \\
\hline $\mathrm{SH}$ & -0.0006 & $-0.0579 * *$ & 1 & & \\
\hline MR & $0.1669 * * *$ & 0.0000 & 0.0000 & 1 & \\
\hline LNMC & 0.0314 & $0.3372 * * *$ & -0.0117 & 0.0054 & 1 \\
\hline \multicolumn{6}{|c|}{ Panel B: March 11-13, 2020} \\
\hline $\mathrm{R}$ & 1 & & & & \\
\hline $\mathrm{PC}$ & $-0.0391 *$ & 1 & & & \\
\hline SH & 0.0041 & $-0.0579 * *$ & 1 & & \\
\hline MR & $0.0671 * * *$ & 0.0000 & 0.0000 & 1 & \\
\hline LNMC & 0.0149 & $0.3356 * * *$ & -0.0146 & 0.0009 & 1 \\
\hline \multicolumn{6}{|c|}{ Panel C: March 26-30, 2020} \\
\hline $\mathrm{R}$ & 1 & & & & \\
\hline $\mathrm{PC}$ & 0.0377 & 1 & & & \\
\hline $\mathrm{SH}$ & $0.0597 * *$ & $-0.0610 * *$ & 1 & & \\
\hline MR & $0.3145^{* * *} *$ & 0.0000 & 0.0000 & 1 & \\
\hline LNMC & $0.1252 * * *$ & $0.3356 * * *$ & -0.0190 & 0.0001 & 1 \\
\hline
\end{tabular}

$R$ daily stock return, $P C$ political connections, $S H$ Sharia compliance, $M R$ daily market return, $L N M C$ natural logarithm of daily market capitalization

$* * * p<1 \%, * * p<5 \%$, and $* p<10 \%$

Indonesian investors' performance actually increased. One plausible explanation for these results is the growth of new investors and daily stock transactions in Indonesia. Even after the first case of COVID-19 and the first case of death caused by COVID19 were confirmed in Indonesia, the number of new investors and daily transactions in the stock market actually increased quite sharply. According to the Indonesia Central Securities Depository (KSEI), ${ }^{2}$ from December 2019 to July 2020, the number of new investors grew by $22 \%$. Meanwhile, from March to July 2020, the average number of daily transactions on the Indonesian stock market grew by $82.4 \%$. It may be that middle- to high-income people became more inclined to invest in the stock market due to various restrictions during the COVID-19 pandemic (e.g., restrictions on traveling and tourism). Hence, in the short term, the Indonesian stock market reacted positively to the COVID-19 outbreak.

Table 4 also shows that for politically connected Sharia-compliant firms, the estimate of CAR was statistically positive for the event windows $[0,0] ;[0,3] ;[0,5]$; and $[0,30]$, whereas for non-politically connected Sharia-compliant firms, the estimate of CAR was statistically positive for the event windows $[0,3]$ and $[0,30]$. These results

\footnotetext{
2 KSEI news, $3^{\text {rd }}$ edition: July-September 2020. Another data source on Single Investor Identification (SID) growth can be seen in the press release by IDX number 114/BEI.SPR/12-2020.
} 


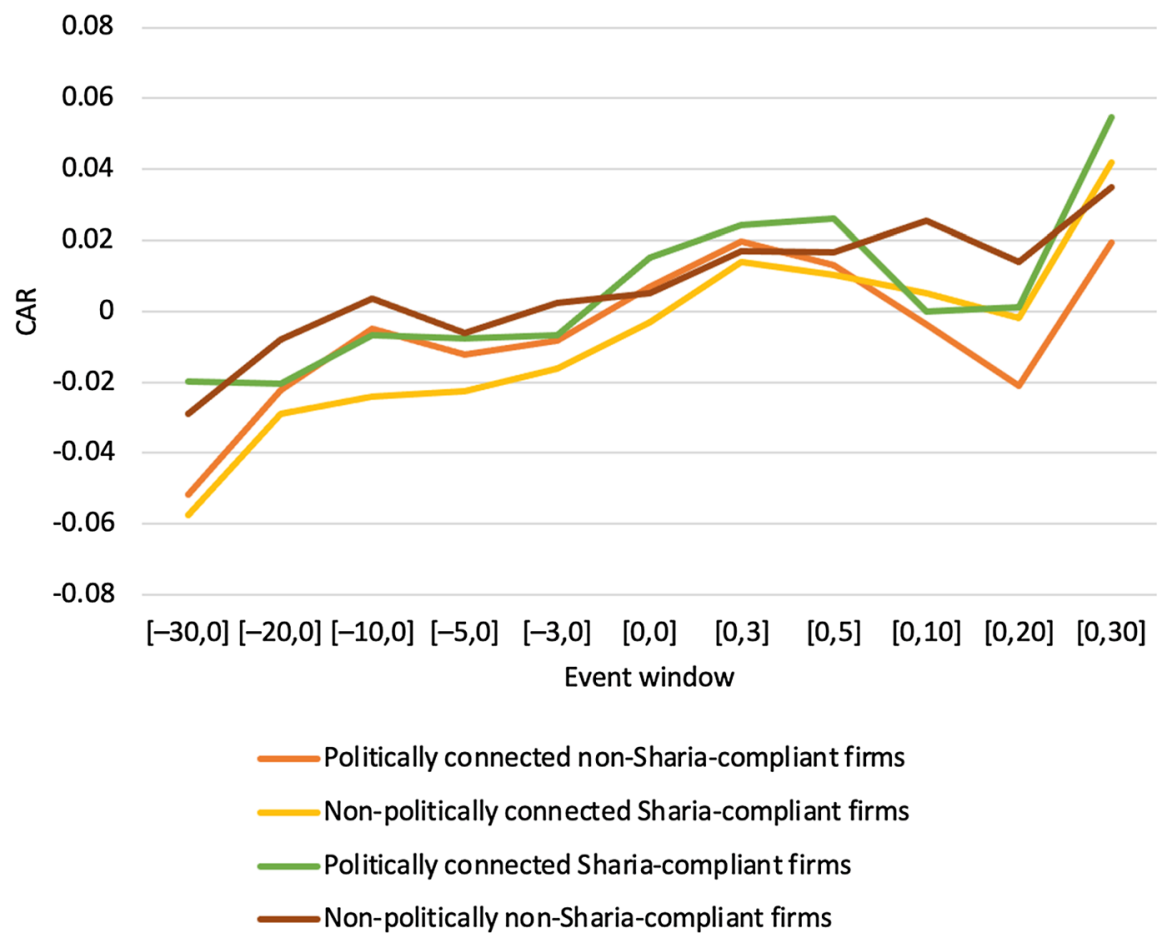

Fig. 3 CAR surrounding the event date

indicate that the positive impact of the COVID-19 pandemic was more pronounced for Sharia-compliant firms (i.e., both non-politically connected Sharia-compliant firms and politically connected Sharia-compliant firms). In line with Fig. 3, the higher CAR is more pronounced after the event window [0,20], i.e., after the government announced tax incentives for firms, indicating that being Sharia-compliant became more valuable during this period. It is worth noting that the increase in CAR may have resulted not only from Sharia compliance but also from political connections, as we divide Sharia-compliant firms into non-politically connected Shariacompliant firms and politically connected Sharia-compliant firms. Hence, to sharpen our investigation of the roles of political connections and Sharia compliance, we rely next on pooled regression analysis of several episodes (Sect. 3.3).

\subsubsection{Sector analysis}

Following previous studies by Al-Awadhi et al. (2020) and He et al. (2020), we analyze the impact of the COVID-19 pandemic on industry sectors. In Indonesia, listed firms are classified into nine industry sectors, namely agriculture; basic industry and chemicals; the consumer goods industry; finance; infrastructure, utilities, and transportation; mining; miscellaneous industries; property, real estate, and building construction; and trade, services, and investment. Then, we divide each industry sector 


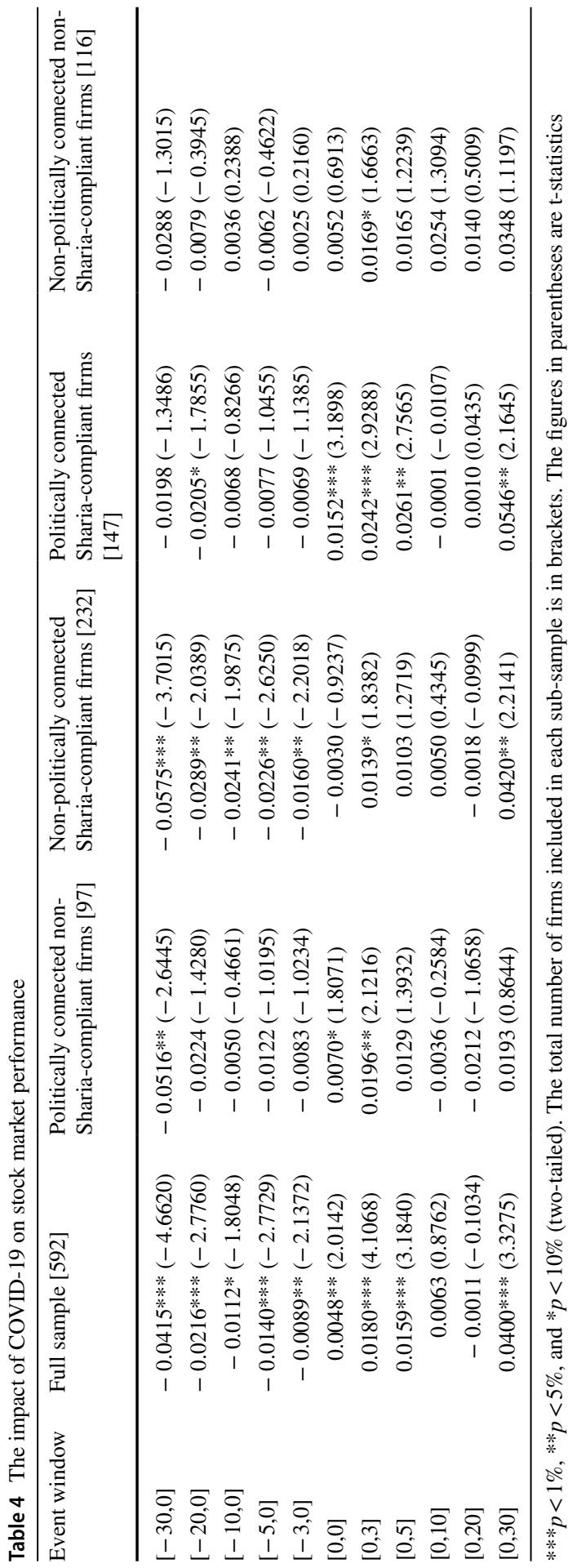




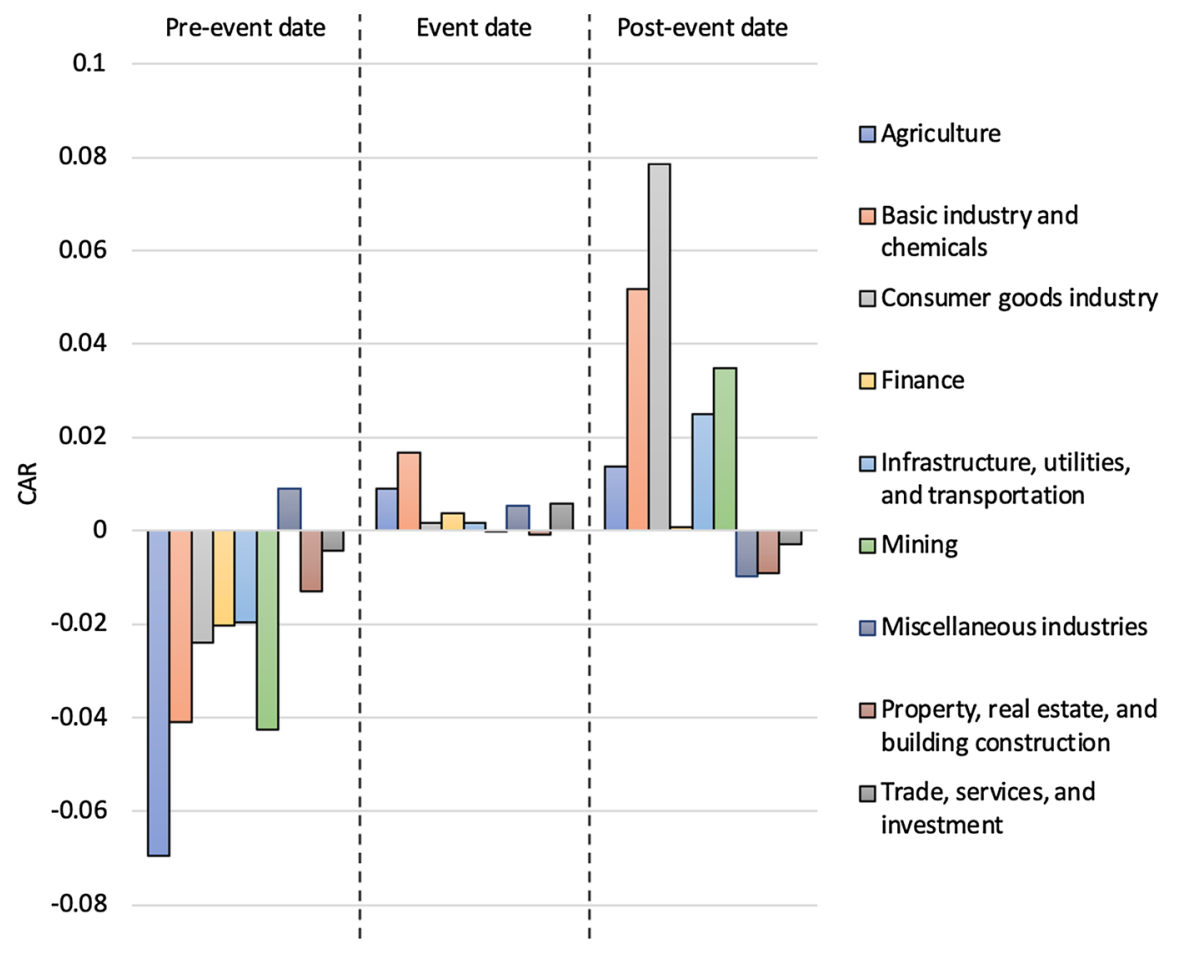

Fig. 4 Sector analysis

into four groups, i.e., politically connected non-Sharia-compliant firms, non-politically connected Sharia-compliant firms, politically connected Sharia-compliant firms, and non-politically connected non-Sharia-compliant firms. However, for the financial sector, there is no politically connected Sharia-compliant firm. Appendix 2 reports the results of the sector analysis. Figure 4 shows a summary of those results.

The results of the sector analysis show that the market reacted positively in the agriculture; basic industry and chemicals; consumer goods industries; infrastructure, utilities, and transportation; and mining sectors. The reasonable explanation for the rise in the agriculture; basic industry and chemicals; and consumer goods industries is that these three sectors are closely related to basic human needs. People will continue to consume products from these three sectors, even during an event such as the COVID-19 pandemic. Furthermore, the positive reaction for infrastructure, utilities, and transportation may have been driven by the telecommunications sub-sector, as the use of telecommunications technology has increased during the COVID-19 pandemic. Moreover, a possible reason for the positive reaction in the mining industry is that it is driven by listed firms with gold products, which tended to strengthen at the beginning of the COVID-19 pandemic. Finally, miscellaneous industries; property, real estate, and building construction; and trade, services, and investment have been negatively impacted by the COVID-19 pandemic. It may be that the social restrictions during the pandemic disrupted the production processes 
of these sectors. Finally, consistent with the baseline event-study analysis, the positive impact detected in the sectoral analysis was more pronounced on Sharia-compliant firms (both non-politically connected Sharia-compliant firms and politically connected Sharia-compliant firms).

\subsubsection{Market capitalization analysis}

We conduct a market capitalization analysis and divide our sample into two groups, i.e., large market capitalization and small market capitalization companies. Following Al-Awadhi et al. (2020), we rank all companies based on their market capitalization and use the 50th percentile as the divider between large market capitalization and small market capitalization companies. Then, we divide each group into politically connected firms, Sharia-compliant firms, politically connected Sharia-compliant firms, and non-politically connected non-Sharia-compliant firms.

The results suggest that firms with a large market capitalization, especially politically connected firms and Sharia-compliant firms, tended to see negative abnormal returns during the COVID-19 pandemic (Table 5). Conversely, firms with a small market capitalization, except politically connected non-Sharia-compliant firms, saw significant abnormal positive returns during the COVID-19 pandemic (Table 6). The COVID-19 pandemic has interacted insignificantly with small market capitalization firms with political connections. It may be that small market capitalization firms have been better positioned to react quickly to the COVID-19 pandemic. Moreover, in line with our baseline and sector analyses, Sharia-compliant firms with small market capitalization seem to have been more valuable during the pandemic.

\subsection{Pooled regression analysis}

Table 7 reports the results from estimating Eq. (3). Panel A presents the first episode regression results (i.e., March 2-4, 2020). Panels B and C show the results for the second episode (i.e., March 11-13, 2020) and the third episode (i.e., March 26-30, 2020), respectively.

Panels A and B of Table 7 show that political connections and Sharia compliance had an insignificant impact on stock returns, indicating that before government intervention, political connections and Sharia compliance seem to have played less of a role during the COVID-19 pandemic. Interestingly, after the government announced tax incentives for companies on account of the COVID-19 pandemic (Panel C of Table 7), Sharia compliance had a positive impact on stock returns. This result is plausible and in line with the Modigliani-Miller (MM) theorem (see Miller, 1977; Modigliani \& Miller, 1958, 1963). According to the MM theorem, debt interest payments can be deducted from taxable corporate income. In other words, firms with higher debt levels are more likely to pay less taxes. Sharia-compliant firms tend to have lower debt, as Sharia screening does not allow firms to take on large amounts of debt (debt limitation), especially interest-based debt. In this regard, Sharia-compliant firms may have benefited from the government's tax incentives during the COVID-19 pandemic. Finally, this 


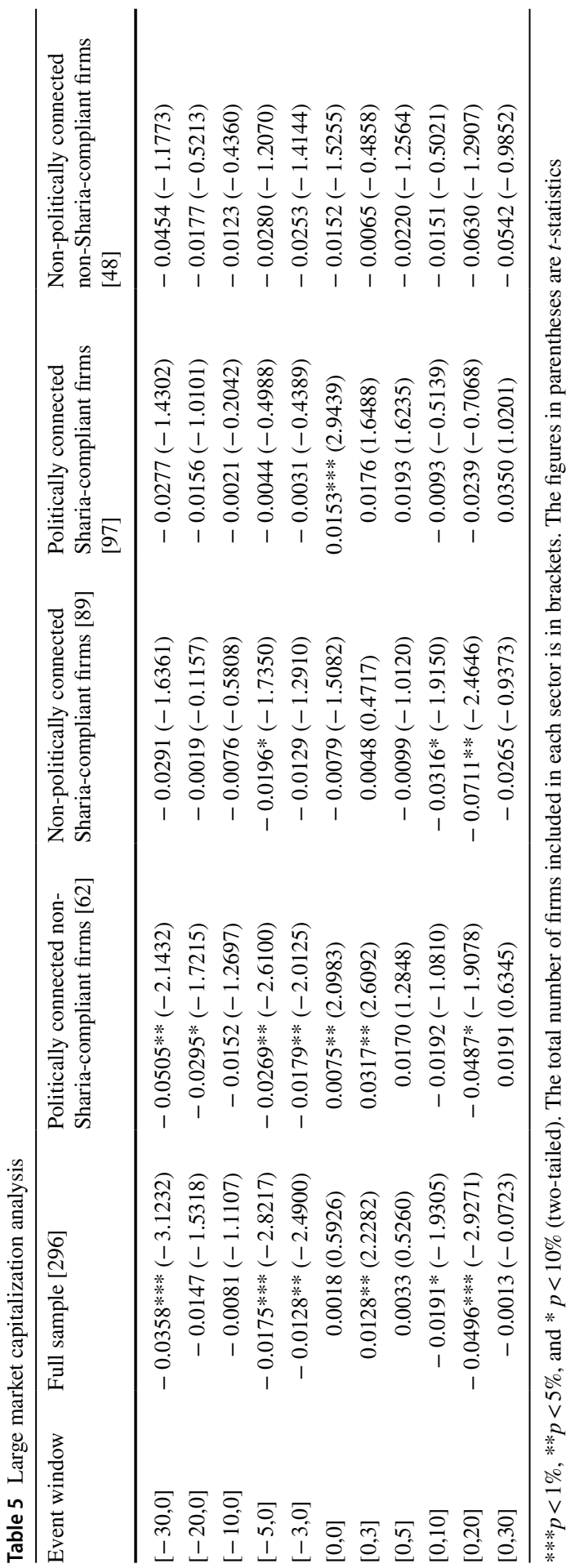




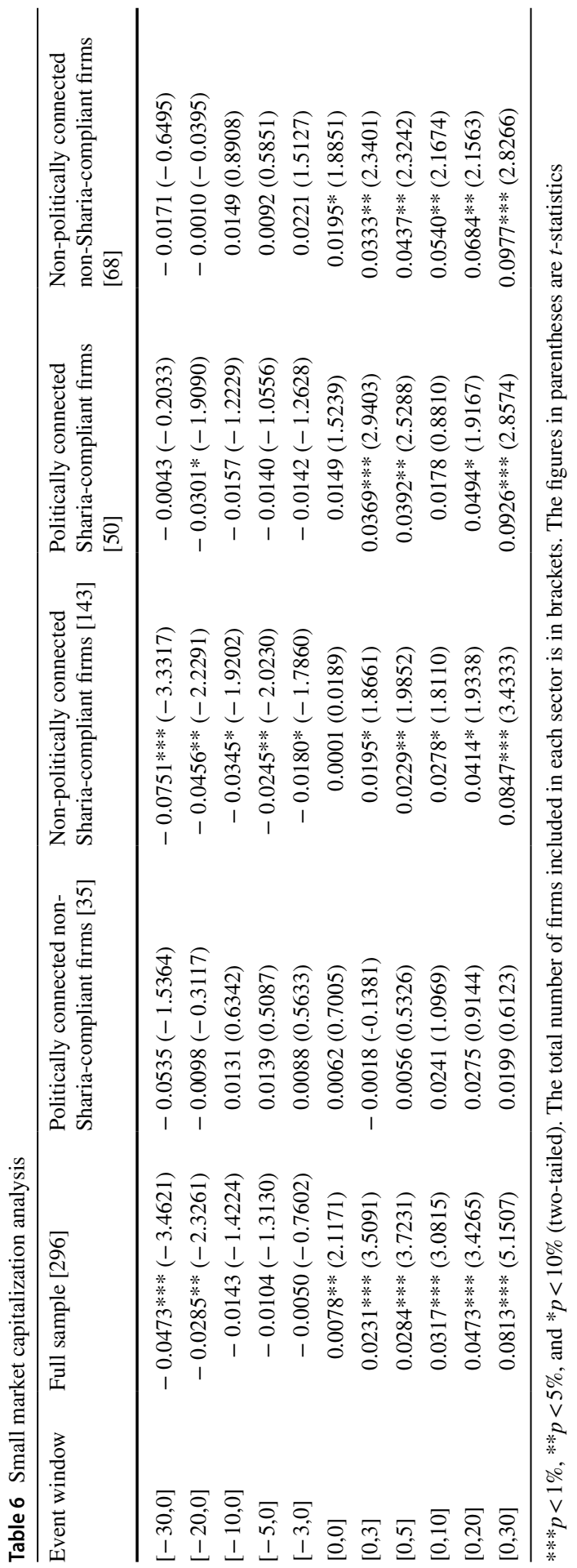


Table 7 Pooled regression analysis

\begin{tabular}{|c|c|c|c|c|}
\hline Variable & Expected sign & (1) & (2) & (3) \\
\hline \multicolumn{5}{|c|}{ Panel A: March 2-4, 2020} \\
\hline Intercept & N/A & $-0.0168(0.0181)$ & $-2.07 \mathrm{e}-02(1.79 \mathrm{e}-02)$ & $-0.0164(0.0180)$ \\
\hline $\mathrm{PC}$ & + & $0.0020(0.0026)$ & & $0.0004(0.0037)$ \\
\hline SH & + & & $-2.64 \mathrm{e}-05(2.58 \mathrm{e}-03)$ & $-0.0010(0.0040)$ \\
\hline $\mathrm{PC} * \mathrm{SH}$ & $+1-$ & & & $0.0024(0.0050)$ \\
\hline MR & + & $0.4520 * * *(0.0624)$ & $4.52 \mathrm{e}-01 * * *(6.24 \mathrm{e}-02)$ & $0.4520 * * *(0.0624)$ \\
\hline LNMC & + & $0.0007(0.0006)$ & $8.79 \mathrm{e}-04(6.29 \mathrm{e}-04)$ & $0.0007(0.0006)$ \\
\hline Obs & & 1776 & 1776 & 1776 \\
\hline \multicolumn{5}{|c|}{ Panel B: March 11-13, 2020} \\
\hline Intercept & N/A & $-0.0835(0.1340)$ & $-0.0443(0.1152)$ & $-0.0854(0.1452)$ \\
\hline $\mathrm{PC}$ & + & $-0.0203(0.0151)$ & & $-0.0157 *(0.0089)$ \\
\hline $\mathrm{SH}$ & + & & $0.0018(0.0078)$ & $0.0039(0.0117)$ \\
\hline $\mathrm{PC} * \mathrm{SH}$ & $+1-$ & & & $-0.0071(0.0120)$ \\
\hline MR & + & $0.6142 * * *(0.0884)$ & $0.6143 * * *(0.0885)$ & $0.6142 * * *(0.0884)$ \\
\hline LNMC & + & $0.0033(0.0054)$ & $0.0016(0.0042)$ & $0.0033(0.0054)$ \\
\hline Obs & & 1776 & 1776 & 1776 \\
\hline \multicolumn{5}{|c|}{ Panel C: March 26-30, 2020} \\
\hline Intercept & N/A & $-0.1311 * * *(0.0198)$ & $-0.1367 * * *(0.0189)$ & $-0.1380 * * *(0.0195)$ \\
\hline $\mathrm{PC}$ & + & $-0.0007(0.0032)$ & & $0.0032(0.0053)$ \\
\hline $\mathrm{SH}$ & + & & $0.0090 * * *(0.0032)$ & $0.0112 * *(0.0047)$ \\
\hline $\mathrm{PC} * \mathrm{SH}$ & $+1-$ & & & $-0.0051(0.0063)$ \\
\hline MR & + & $0.4036^{* * *}(0.0331)$ & $0.4036 * * *(0.0331)$ & $0.4036^{* * * *}(0.0331)$ \\
\hline LNMC & + & $0.0047 * * *(0.0007)$ & $0.0046^{* * *}(0.0007)$ & $0.0046^{* * * *}(0.0007)$ \\
\hline Obs & & 1776 & 1776 & 1776 \\
\hline
\end{tabular}

$* * * p<1 \%, * * p<5 \%$, and $* p<10 \%$. PC is political connections, SH is Sharia compliance, MR is daily market return, and LNMC is the natural logarithm of daily market capitalization. The figures in brackets are heteroscedasticity-robust standard errors

result indicates that being a Sharia-compliant firm was valuable during the COVID-19 pandemic when the government was giving tax incentives.

\subsection{Robustness check}

We consider using two kinds of robustness tests. First, to check the robustness of the event-study analysis, we use a longer estimation window to calculate CAR. Second, we use another Sharia compliance proxy to check whether or not the regression results are robust. 


\subsubsection{Using a longer estimation window}

To calculate CAR in the baseline event-study analysis, we use 120 trading days before the event date as an estimation window $[-140,-20]$. Then, as a robustness test, we use 230 trading days before the event date $[-250,-20]$.

Table 8 shows that the market reacted positively to the COVID-19 pandemic, especially for politically connected Sharia-compliant firms. Thus, the robustness results using a longer estimation window support the main findings.

\subsubsection{An alternative Sharia compliance measurement}

Our baseline regression analysis finds that Shariah compliance was more valuable during the COVID-19 pandemic after the government announced tax incentives for firms. To check the robustness of our baseline results, we use another measurement of Sharia compliance. We consider using listed firms in Jakarta Islamic Index (JII) ${ }^{3}$ as another Sharia compliance proxy, and then repeat Eq. (3).

As reported in Table 9, the regression results using another proxy for Sharia compliance are basically similar to the main results, i.e., Sharia compliance has been valuable during the COVID-19 pandemic, especially when the government announced tax incentives for firms. Hence, our baseline results are robust to another Sharia compliance proxy.

\section{Conclusions}

This study aimed to examine the value of political connections and Sharia compliance for firms during the COVID-19 pandemic in the Indonesian stock market. We summarize the findings as follows. First, we find that there was a stock market anomaly during the COVID-19 pandemic in Indonesia in that the pandemic interacted positively with the Indonesian stock market. Thus, there has been an increase in investors' performance during the COVID-19 pandemic. Second, our sectoral event-study analysis found that industry sectors closely related to human needs (i.e., agriculture; basic industry and chemicals; consumer goods industries) tended to see a positive increase in their market value. In addition, our market capitalization analysis results indicate that firms with a small market capitalization tended to see a positive increase in their market value. Third, our event-study analysis (i.e., baseline, sectoral, and market capitalization analysis) shows that the positive reactions of the market to the COVID-19 pandemic were more pronounced in the case of Sharia-compliant firms (both those with and without political connections). Then, we conduct pooled regression analysis to sharpen our investigation on the role of Sharia compliance and political connections. We find that political connections played no significant role during the COVID-19 pandemic in Indonesia. However, we find

\footnotetext{
${ }^{3}$ JII was the first Sharia stock index in the Indonesian capital markets; it consists of only the 30 most liquid Sharia stocks listed on the IDX.
} 


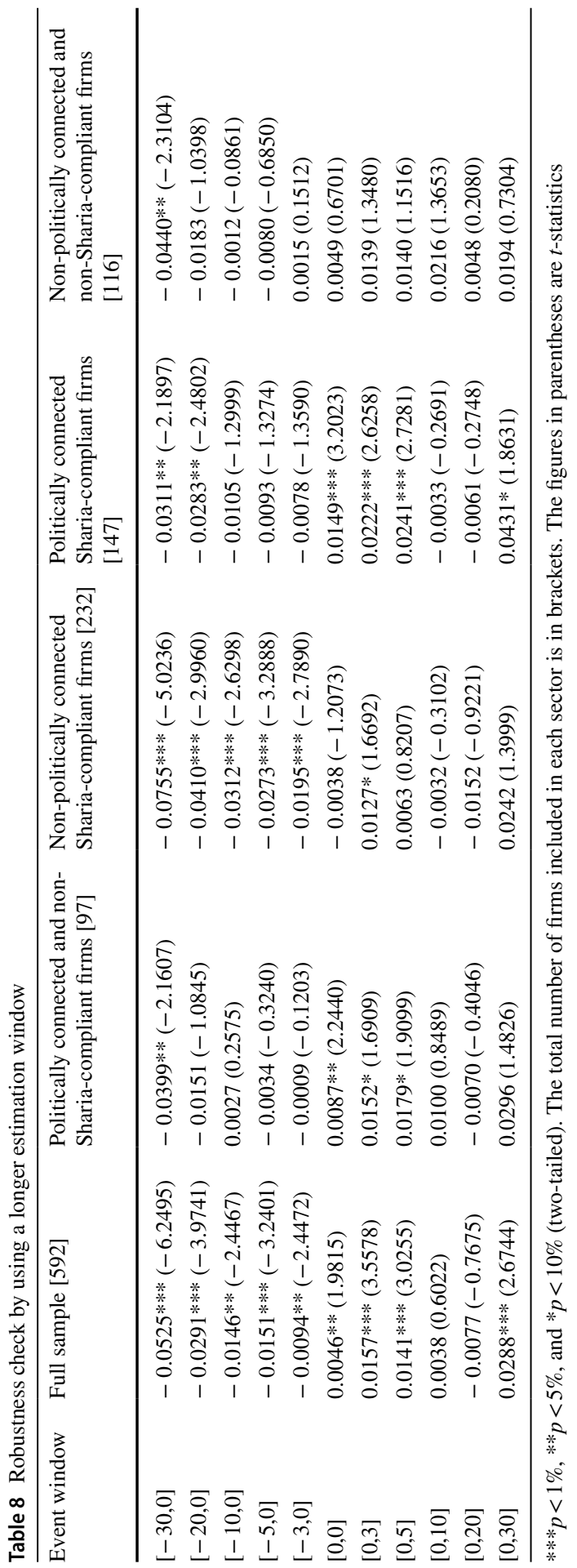


Table 9 Robustness check using an alternative Sharia compliance measurement

\begin{tabular}{|c|c|c|c|c|}
\hline Variable & Expected sign & (1) & (2) & (3) \\
\hline \multicolumn{5}{|c|}{ Panel A: March 2-4, 2020} \\
\hline Intercept & N/A & $-0.0168(0.0181)$ & $-0.0204(0.0183)$ & $-0.0171(0.0184)$ \\
\hline $\mathrm{PC}$ & + & $0.0020(0.0026)$ & & $0.0022(0.0027)$ \\
\hline $\mathrm{SH}$ & + & & $-0.0010(0.0029)$ & $0.0011(0.0040)$ \\
\hline $\mathrm{PC} * \mathrm{SH}$ & $+1-$ & & & $-0.0055(0.0056)$ \\
\hline MR & + & $0.4520 * * *(0.0624)$ & $0.4519 * * *(0.0624)$ & $0.4520 * * *(0.0624)$ \\
\hline LNMC & + & $0.0007(0.0006)$ & $0.0009(0.0006)$ & $0.0007(0.0006)$ \\
\hline Observations & & 1776 & 1776 & 1776 \\
\hline \multicolumn{5}{|c|}{ Panel B: March 11-13, 2020} \\
\hline Intercept & N/A & $-0.0835(0.1390)$ & $-0.0450 * *(0.0182)$ & $-0.0371(0.0248)$ \\
\hline $\mathrm{PC}$ & + & $-0.0203(0.0151)$ & & $-0.0050^{*}(0.0026)$ \\
\hline $\mathrm{SH}$ & + & & $0.0741(0.0900)$ & $0.2920(0.2874)$ \\
\hline $\mathrm{PC} * \mathrm{SH}$ & $+1-$ & & & $-0.3109(0.2875)$ \\
\hline MR & + & $0.6142 * * *(0.0884)$ & $0.6146 * * *(0.0888)$ & $0.6145 * * *(0.0888)$ \\
\hline LNMC & + & $0.0033(0.0054)$ & $-0.0017 * * *(0.0007)$ & $-0.0014(0.0009)$ \\
\hline Observations & & 1776 & 1776 & 1776 \\
\hline \multicolumn{5}{|c|}{ Panel C: March 26-30, 2020} \\
\hline Intercept & N/A & $-0.1311 * * *(0.0198)$ & $-0.1139 * * *(0.0198)$ & $-0.1164 * * *(0.0209)$ \\
\hline $\mathrm{PC}$ & + & $-0.0007(0.0032)$ & & $-0.0013(0.0033)$ \\
\hline $\mathrm{SH}$ & + & & $0.0134 * *(0.0066)$ & $0.0055(0.0124)$ \\
\hline $\mathrm{PC} * \mathrm{SH}$ & $+1-$ & & & $0.0113(0.0140)$ \\
\hline MR & + & $0.4036 * * *(0.0331)$ & $0.4036 * * *(0.0331)$ & $0.4036 * * *(0.0331)$ \\
\hline LNMC & + & $0.0047 * * *(0.0007)$ & $0.0040 * * *(0.0007)$ & $0.0041 * * *(0.0008)$ \\
\hline Observations & & 1776 & 1776 & 1776 \\
\hline
\end{tabular}

$* * * p<1 \%, * * p<5 \%$, and $* p<10 \%$. PC is political connections, SH is Sharia compliance, MR is daily market return, and LNMC is the natural logarithm of daily market capitalization. The figures in brackets are heteroscedasticity-robust standard errors

strong evidence that Sharia compliance was beneficial for firms during the COVID19 pandemic when the government announced tax incentives. These findings are robust to a longer estimation window for event-study analysis and another Sharia compliance proxy for pooled regression analysis. Taken together, our findings suggest that being Sharia-compliant has been valuable during the COVID-19 pandemic due to the announcement of tax incentives by the government.

The results of this study have several practical implications. First, the existence of a stock market anomaly implies investors' confidence in future returns and in an eventual market recovery. Therefore, financial market authorities should implement strategies to maintain and even increase investors' confidence. In addition, the government should intervene by implementing stimulus packages to alleviate stock market panic. Second, the positive market value is more pronounced in the case of Sharia-compliant firms in particular industry sectors. One of the factors that drove the market value of Sharia-compliant firms was the tax incentives announcement 
by the government. In this regard, policymakers should devise further policies for managing tax incentives and consider their potential impact on firms' value during the pandemic. Third, from a wider perspective, the results of this study provide support for the position that adopting Islamic law (Sharia) can be considered a viable financial alternative during the pandemic. Finally, this study also provides important insights for investors. The findings can assist prospective investors in their investment decision-making on the stock market. Moreover, investors should also learn how to manage their portfolio risks, given the continued spread of COVID-19 in Indonesia.

As with all studies, our study is not without its limitations. First, we only investigated the short-term impact of the COVID-19 pandemic on the Indonesian stock market because of the short event period. The long-term impact of the COVID-19 pandemic may be different from its short-term impact. Second, for the purposes of our regression analysis, we only considered three episodes at the beginning of the COVID-19 pandemic in Indonesia, i.e., the first case of COVID-19, the first death case caused by COVID-19, and the tax incentives announcement. There are still other important events related to COVID-19 in Indonesia, e.g., when the government published a regulation on large-scale social restrictions. The most appropriate imminent expansion for future study would be to investigate the long-term impact of COVID-19 in Indonesia. In addition, future research should also consider looking into other important events related to COVID-19 in Indonesia.

\section{Appendix 1}

See Table 10.

Table 10 The Breusch-Pagan Lagrange Multiplier test

\begin{tabular}{llll}
\hline Regression model & 1 & 2 & 3 \\
\hline$\chi^{2}$ & 0.02 & 0.00 & 2.16 \\
$P$ value & 0.4487 & 1.0000 & 0.0708 \\
\hline
\end{tabular}

Regression model 1 is for episode 1 (March 2-4, 2020); regression model 2 is for episode 2 (March 11-13, 2020); and regression model 3 is for episode 3 (March 26-30, 2020)

\section{Appendix 2}

See Tables 11, 12, 13, 14 and 15 . 


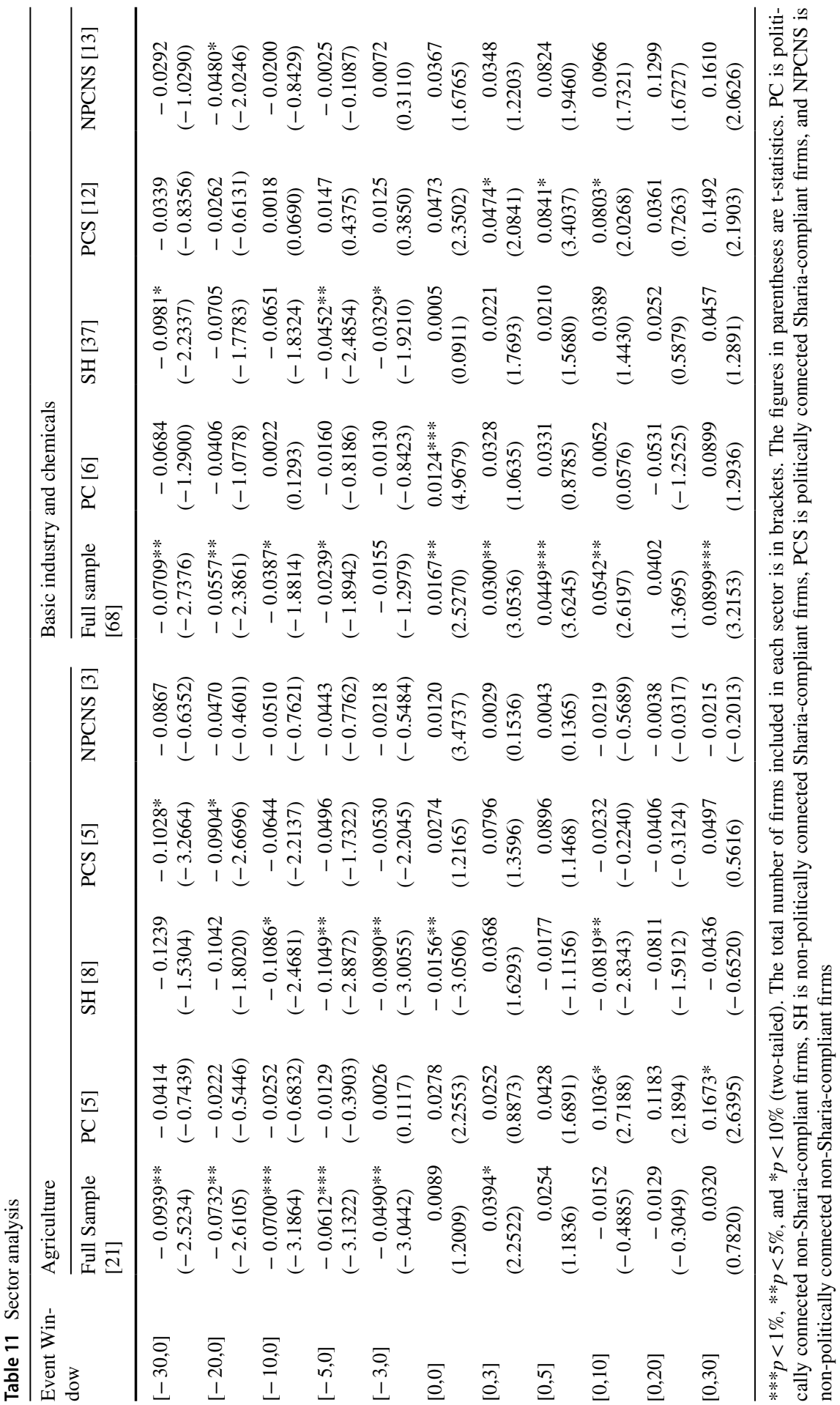




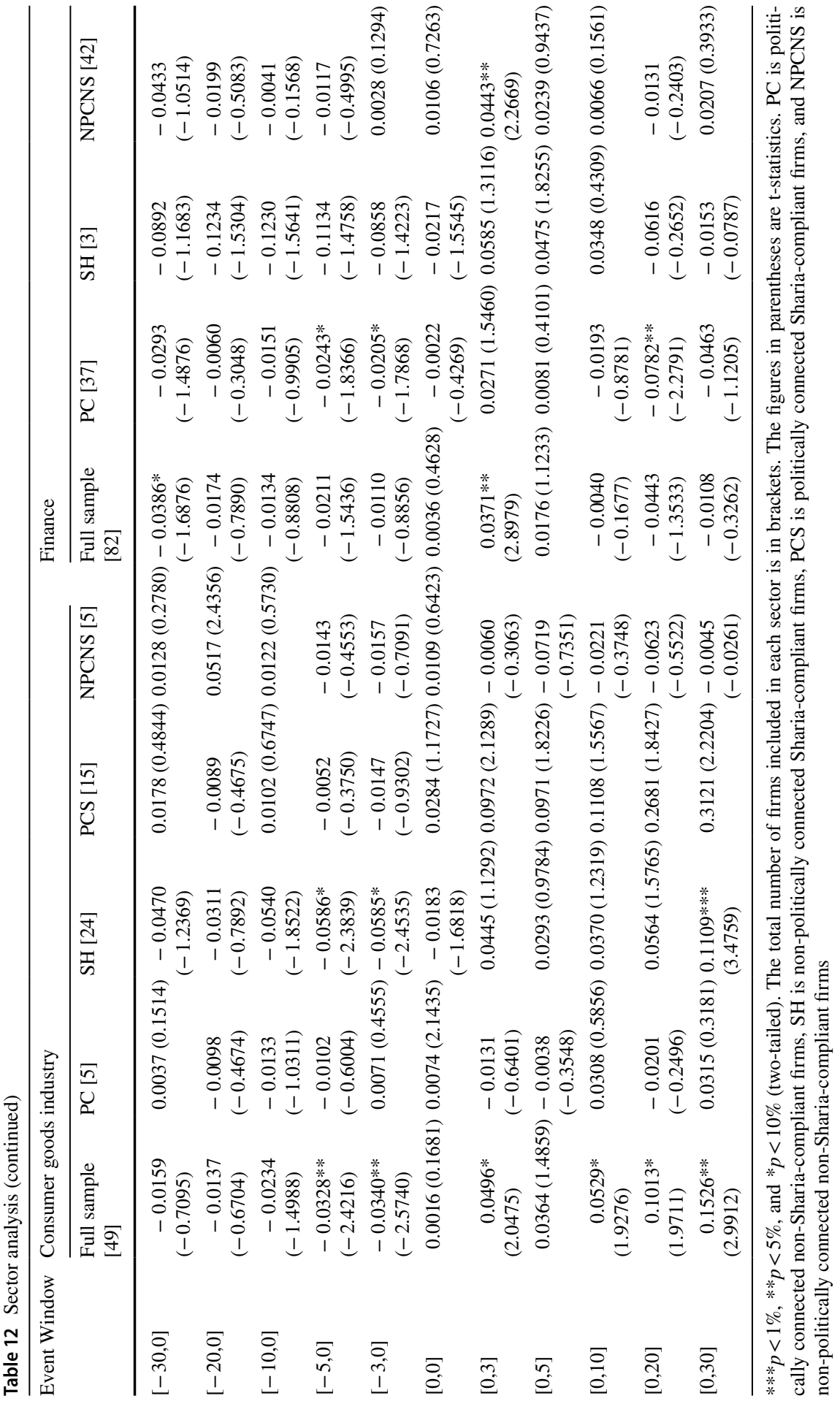




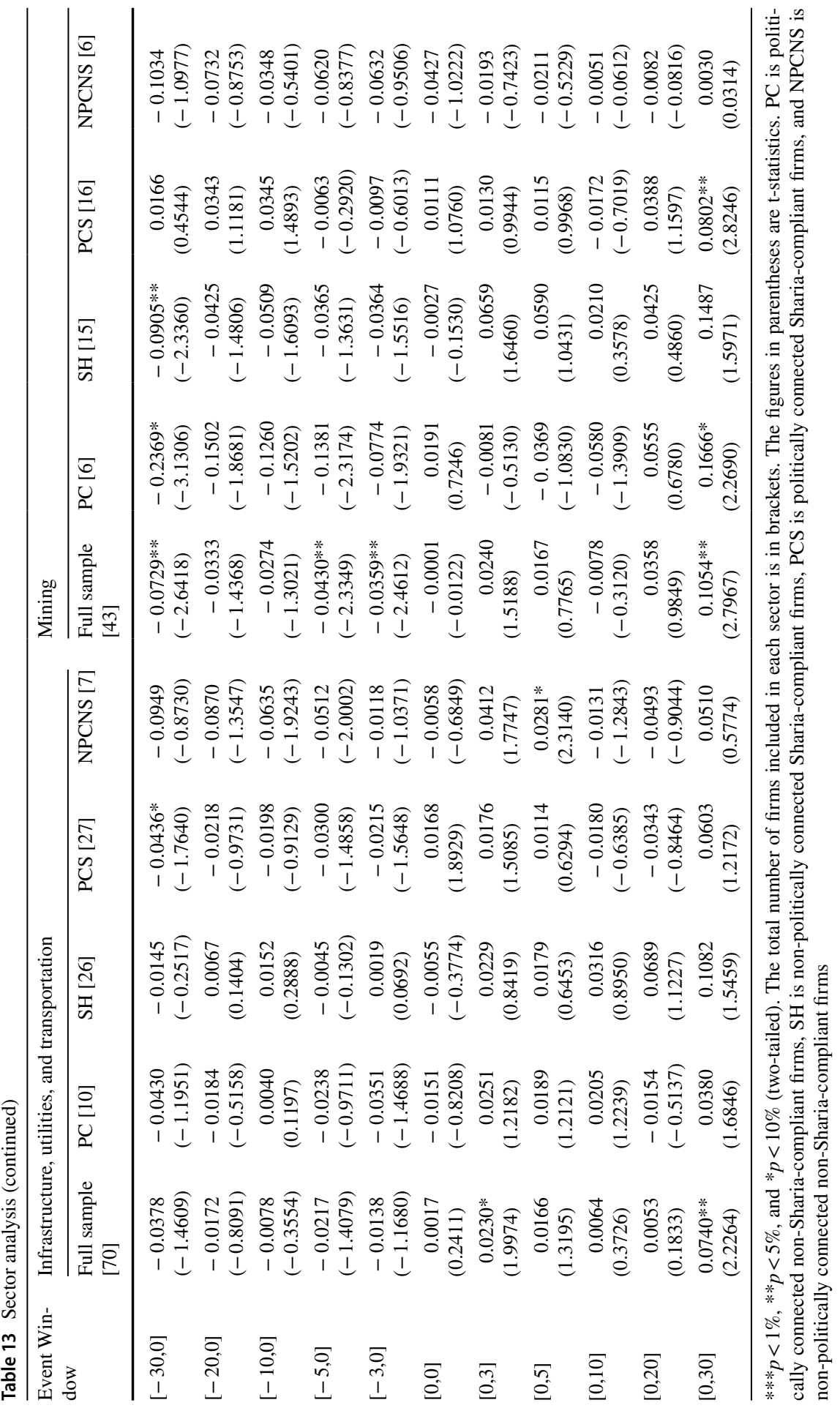




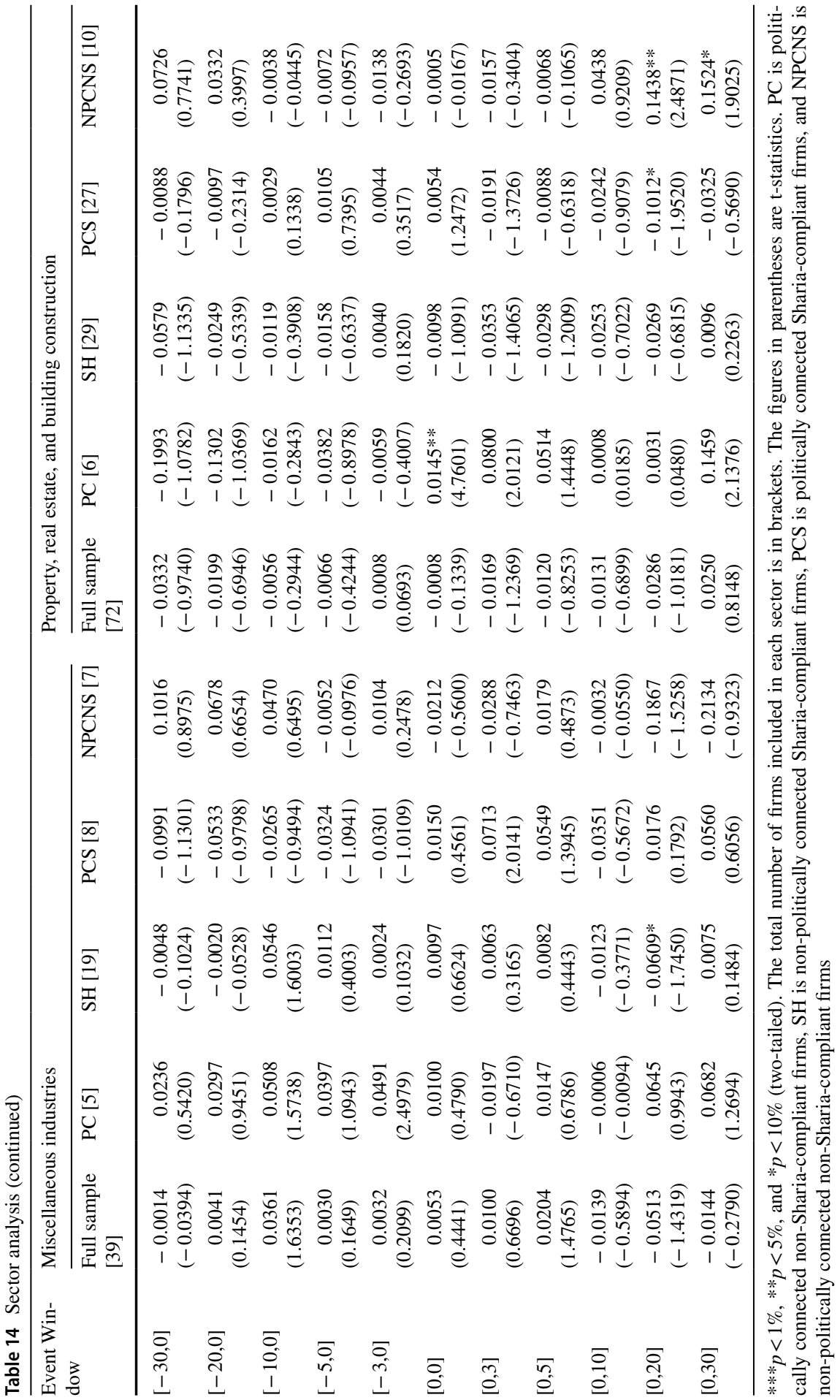




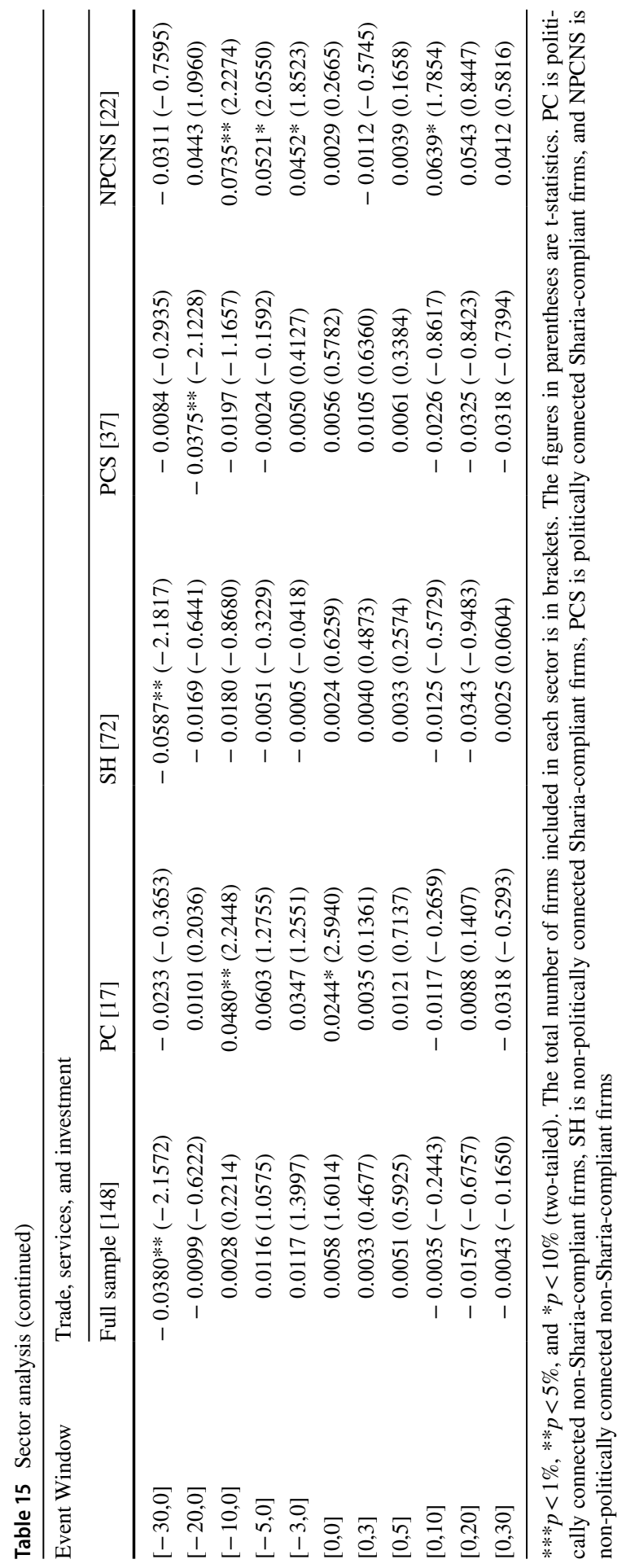


Funding This research did not receive any specific grant from funding agencies in the public, commercial, or not-for-profit sectors.

Availability of data and material The datasets generated during and/or analyzed during the current study are available from the corresponding author on reasonable request.

Code availability Data analysis in this study used software Microsoft Excel for Mac Version 16.50 (21061301) and RStudio Version 1.3.1093.

\section{Declarations}

Conflict of interest The authors declare no competing interests.

\section{References}

Abduh, M. (2020). Volatility of Malaysian conventional and Islamic indices: Does financial crisis matter? Journal of Islamic Accounting and Business Research, 11(1), 1-11. https://doi.org/10.1108/ JIABR-07-2017-0103

Al-Awadhi, A. M., Alsaifi, K., Al-Awadhi, A., \& Alhammadi, S. (2020). Death and contagious infectious diseases: Impact of the COVID-19 virus on stock market returns. Journal of Behavioral and Experimental Finance. https://doi.org/10.1016/j.jbef.2020.100326

Al-Khazali, O., Lean, H. H., \& Samet, A. (2014). Do Islamic stock indexes outperform conventional stock indexes? A stochastic dominance approach. Pacific Basin Finance Journal, 28, 29-46. https:// doi.org/10.1016/j.pacfin.2013.09.003

Al-Suhaibani, M., \& Naifar, N. (2014). Islamic corporate governance: Risk-sharing and Islamic preferred shares. Journal of Business Ethics, 124(4), 623-632. https://doi.org/10.1007/s10551-013-1897-6

Ashraf, B. N. (2020). Stock markets' reaction to COVID-19: Cases or fatalities? Research in International Business and Finance. https://doi.org/10.1016/j.ribaf.2020.101249

Baek, S., Mohanty, S. K., \& Glambosky, M. (2020). COVID-19 and stock market volatility: An industry level analysis. Finance Research Letters. https://doi.org/10.1016/j.frl.2020.101748

Baker, S. R., Bloom, N., Davis, S. J., Kost, K., \& Sammon, M. (2020). The unprecedented stock market reaction to COVID-19. Review of Asset Pricing Studies, 10, 742-758. https://doi.org/10.1093/rapstu/raaa008

Brown, S. J., \& Warner, J. B. (1985). Using daily stock returns: The case of event studies. Journal of Financial Economics, 14, 3-31.

Chen, M. H., Jang, S. C., \& Kim, W. G. (2007). The impact of the SARS outbreak on Taiwanese hotel stock performance: An event-study approach. International Journal of Hospitality Management, 26(1), 200-212. https://doi.org/10.1016/j.ijhm.2005.11.004

Duchin, R., \& Sosyura, D. (2012). The politics of government investment. Journal of Financial Economics, 106, 24-48. https://doi.org/10.1016/j.jfineco.2012.04.009

Faccio, M. (2006). Politically connected firms. The American Economic Review. https://doi.org/10.1257/ 000282806776157704

Faccio, M., Masulis, R. W., \& Mcconnell, J. J. (2006). Political connections and corporate bailouts. Journal of Finance, 61(6), 2597-2635. https://doi.org/10.1111/j.1540-6261.2006.01000.x

Fakhfekh, M., Jeribi, A., \& Ben Salem, M. (2021). Volatility dynamics of the Tunisian stock market before and during the COVID-19 outbreak: Evidence from the GARCH family models. International Journal of Finance and Economics. https://doi.org/10.1002/ijfe.2499

Farooq, O., \& AbdelBari, A. (2015). Earnings management behaviour of Shariah-compliant firms and non-Shariah-compliant firms: Evidence from the MENA region. Journal of Islamic Accounting and Business Research, 6(2), 173-188. https://doi.org/10.1108/ARA-11-2013-0076

Fisman, R. (2001). Estimating the value of political connections. The American Economic Review, 91(4), 1095-1102.

Fu, J., Shimamoto, D., \& Todo, Y. (2017). Can firms with political connections borrow more than those without? Evidence from firm-level data for Indonesia. Journal of Asian Economics, 52, 45-55. https://doi.org/10.1016/j.asieco.2017.08.003 
Griffith, R., Levell, P., \& Stroud, R. (2020). The impact of COVID-19 on share prices in the UK. Fiscal Studies, 41(2), 363-369. https://doi.org/10.1111/1475-5890.12226

Habib, A., Haris, A., \& Jiang, H. (2017). Political connections and related party transactions: Evidence from Indonesia. International Journal of Accounting, 52(1), 45-63. https://doi.org/10.1016/j.intacc.2017.01.004

He, P., Sun, Y., Zhang, Y., \& Li, T. (2020). COVID-19's Impact on stock prices across different sectors-an event study based on the Chinese stock market. Emerging Markets Finance and Trade, 56(10), 2198-2212. https://doi.org/10.1080/1540496X.2020.1785865

Hong, H., Bian, Z., \& Lee, C. C. (2021). COVID-19 and instability of stock market performance: Evidence from the U.S. Financial Innovation. https://doi.org/10.1186/s40854-021-00229-1

Hu, Y., Wang, C., Xiao, G., \& Zeng, J. (2020). The agency cost of political connections: Evidence from China's File 18. Pacific Basin Finance Journal. https://doi.org/10.1016/j.pacfin.2020.101426

Jagolinzer, A. D., Larcker, D. F., Ormazabal, G., \& Taylor, D. J. (2020). Political connections and the informativeness of insider trades. Journal of Finance, 75(4), 1833-1876. https://doi.org/10.1111/jofi.12899

Liu, H., Manzoor, A., Wang, C., Zhang, L., \& Manzoor, Z. (2020). The COVID-19 outbreak and affected countries stock markets response. International Journal of Environmental Research and Public Health. https:// doi.org/10.3390/ijerph17082800

MacKinlay, A. C. (1997). Event studies in economics and finance. Journal of Economic Literature, 35(1), 13-39.

Miller, M. H. (1977). Debt and taxes. Journal of Finance, XXXII(2), 261-275.

Modigliani, F., \& Miller, M. H. (1958). The cost of capital, corporate finance and the theory of investment. American Economic Review, 48(3), 261-297. https://doi.org/10.2307/1286430

Modigliani, F., \& Miller, M. H. (1963). Corporate income taxes and the cost of capital: A correction. American Economic Review, 53(3), 433-443.

Omura, A., Roca, E., \& Nakai, M. (2021). Does responsible investing pay during economic downturns: Evidence from the COVID-19 pandemic. Finance Research Letters. https://doi.org/10.1016/j.frl.2020.101914

Qian, M., Pan, H., \& Yeung, B. Y. (2012). Expropriation of minority shareholders in politically connected firms. SSRN Electronic Journal. https://doi.org/10.2139/ssrn.1719335

Ryandono, M. N. H., Muafi, M., \& Guritno, A. (2021). Sharia stock reaction against COVID-19 pandemic: Evidence from Indonesian capital markets. Journal of Asian Finance, Economics and Business, 8(2), 697710. https://doi.org/10.13106/jafeb.2021.vol8.no2.0697

Safieddine, A. (2009). Islamic financial institutions and corporate governance: New insights for agency theory. Corporate Governance: An International Review, 17(2), 142-158. https://doi.org/10.1111/j.1467-8683. 2009.00729.x

Sharif, A., Aloui, C., \& Yarovaya, L. (2020). COVID-19 pandemic, oil prices, stock market, geopolitical risk and policy uncertainty nexus in the US economy: Fresh evidence from the wavelet-based approach. International Review of Financial Analysis. https://doi.org/10.1016/j.irfa.2020.101496

Sherif, M. (2020). The impact of Coronavirus (COVID-19) outbreak on faith-based investments: An original analysis. Journal of Behavioral and Experimental Finance. https://doi.org/10.1016/j.jbef.2020.100403

Topcu, M., \& Gulal, O. S. (2020). The impact of COVID-19 on emerging stock markets. Finance Research Letters. https://doi.org/10.1016/j.frl.2020.101691

Vukovic, V. (2021). The politics of bailouts: Estimating the causal effects of political connections on corporate bailouts during the 2008-2009 US financial crisis. Public Choice. https://doi.org/10.1007/ s11127-020-00871-w

Wagner, A. F. (2020). What the stock market tells us about the post-COVID-19 world. Nature Human Behaviour. https://doi.org/10.1038/s41562-020-0869-y

Wang, L., \& Lin, P. T. (2017). Who benefits from political connections? Minority investors or controlling shareholders. Asia-Pacific Journal of Accounting and Economics, 24(1-2), 1-22. https://doi.org/10.1080/16081 625.2016 .1151364

WHO. (2020a). Coronavirus disease 2019 situation report 51-11th March 2020. https://apps. who.int/iris/ handle/10665/331475

WHO. (2020b). Novel coronavirus (2019-nCoV) situation report-1 - 21 January 2020. https://www.who. int/emergencies/diseases/novel-coronavirus-2019/situation-reports

Youssef, M., Mokni, K., \& Ajmi, A. N. (2021). Dynamic connectedness between stock markets in the presence of the COVID-19 pandemic: Does economic policy uncertainty matter? Financial Innovation. https://doi. org/10.1186/s40854-021-00227-3 
Publisher's Note Springer Nature remains neutral with regard to jurisdictional claims in published maps and institutional affiliations. 